\title{
AORTO-CORONARY BYPASS IN A PATIENT WITH SICKLE CELL TRAIT
}

\author{
Maurice Heiner, S.J. Teasdale. T. David. A.A. Scotr and M.F.X. Glynn
}

IN GENERAL, individuals heterozygous for haemoglobin $S$ in their red cells manifest few signs of the sickle cell trait unless exposed to an hypoxic environment. 1.2 Similarly, they have usually withstood anaesthesia and surgery well. and do not develop clinical evidence of intravascular sickle cell transformation with attendant vascular occlusions, unless acidosis, hypoxaemia, hypotension or prolonged stasis develop.

Most of the accounts dealing with sickle cell trait and surgery emphasize that if acidosis, hypoxaemia and hypotension are prevented, the risk of the red cells undergoing sickle cell transformation is slight. ${ }^{3-10}$ However, the anaesthetic and surgical procedures in those instances were relatively uncomplicated: acid base status haemostasis and adequate oxygenation were relatively simple to maintain. In particular, extracorporeal circulation was not needed. Despite this, the interaction of sickle cell trait and anaesthesia has led to severe morbidity" and even to fatal outcomes. ${ }^{\mathrm{B} .12}$

During cardiopulmonary bypass surgery, the problems are greatly magnified. Hypoxia from alveolar or oxygenator hypoventilation, hy. potension, alterations in temperature and acidaemia may occur. Thus, patients with sickle cell trait are at increased risk of intravascular sickling resulting in intravascular thrombi, tissue necrosis and baemolysis, during procedures which require the use of cardiopulmonary bypass. That this risk in cardiovascular surgery is substantial was illustrated in a patient with sickle cell trait reported by Leachman and colleagues in

Maurice Heiner, M.D., F.R.C.P.(C). Research Fellow. Dept. of Anaesthesia \& Cardiovasular Surgery, Toronto General Hospital \& Banting Institute, Toronto. S.J. Teasdale, M.D. F.R.C.P.(C). Director, Cardiovascular Intensive Care Unit. Dept. of Anaesthesia, Toronto General Hospital. Toronto. T. David. M.D. F.R.C.S.(C). Cardiovascular Surgeon, Toronto General Hospital, Toronto. A.A. Scott. M.D. F.R.C.P.(C), Professor and Chairman, Dept. of Anaesthesia, University of Toronto \& Anaesthetistin-Chief, Toronto General Hospital, Toronto. M.F.X. Glynn, M.D. F.R.C.P.(C). Staff Physician-in-Charge, Coagulation Laboratory, Toronto General Hospital, Toronto. whom sickle cell thrombi produced widespread damage and death in the immediate postoperative period. "3

We wish to report the management of a patient with sickle cell trait and severe coronary artery disease. Bearing in mind the cases cited above and the risks inherent in cardiac surgery with extracorporeal circulation, exchange transfusions were used before the surgery to limit the amount of sickling possible and, hence. the damage from ischaemia or hypotension. ${ }^{14}$ Only red blood cells containing haemoglobin $\mathrm{S}$ can undergo the sickle cell transformation.

Donor blood, screened for hepatitis, can be tested by electrophoretic techniques to determine that the red cells contain only haemoglobin A. By exchanging blood containing exclusively haemoglobin A for the patient's own blood, the cells which could passibly undergo sickle formation would be limited to the residual population of the patient's own cells, since only these cells contain haemoglobin S. This approach has been used before with success. ${ }^{15}$ We also decided to employ the recently described endocardial viability ratio (EVR) apparatus to see if this could help us evaluate myocardial tissue perfusion more completely and so warn us early of impending ischaemia.

\section{CAsE Report}

A 57-year-old Jamaican male of mixed racial origin was admitted to the Toronto General Hospital with a 10-year history of angina pectoris which had been increasing in severity for eight months before admission. Medical therapy with propranolol (Inderal) $240 \mathrm{mg} / \mathrm{day}$, isosorbid dinitrate (Isordil) $20 \mathrm{mg} / \mathrm{day}$ and nitroglycerin paste on retiring, failed to provide relief of his anginal distress. The patient was admitted for monitoring of his heart and assessment of his heart disease including radiological visualization of the coronary arteries.

His past history included unilateral varicose veins with ligation and an episode of "pyelonephritis" as a child. He had had no recurrences of kidney or urinary infection. 
Family history was helpful in that the sickle cell trait was present in two of the patient's brothers and one of his sisters. He denied specific knowledge of having sickle cell trait himself.

Shortly after admission he sufferend an episode of severe and prolonged chest pain which required morphine for relief. Serial enzyme studies and electrocardiograms failed to reveal any evidence of infarction. The electrocardiogram showed non-specific T-wave changes in all leads and a diagnosis of acute coronary insufficiency was made.

Laboratory findings and haematological investigations revealed a haemoglobin concentration of $10.1 \mathrm{gm} / \mathrm{dl}$, of which haemoglobin $A$ was $62 \mathrm{per}$ cent, haemoglobin $S$ was 36 per cent and haemoglobin $A_{2}$ was slightly less than two per cent. All other laboratory values including urinalysis, blood creatinine and blood urea nitrogen were within reference standard limits.

Heart catheterization revealed significant disease in all three coronary arteries with over 80 per cent occlusion of the left anterior descending coronary artery. Left ventricular function was well preserved with no areas of abnormal or paradoxical contraction. Accordingly it was de. cided to attempt bypass grafts of the coronary arteries, in particular the anterior descending coronary artery.

\section{Materials and Methods}

\section{Haematological studies}

Haemoglobin was measured in a Coulter Counter, Model S (Coulter Electronics, Hialeah, Florida, U.S.A.). Haemoglobin S was measured by electrophoresis on a starch gel support medium. ${ }^{16.17}$ The percentage of sickle cells was calculated from blood films by the technique described by Sherman. ${ }^{18}$

\section{The Sherman lest}

The dead space in a $5 \mathrm{ml}$ Luer glass syringe was filled with white oil, the excess being expelled. Without exposure to air, $2 \mathrm{ml}$ of blood was drawn into the syringe. One $\mathrm{ml}$ of this blood was injected into $2 \mathrm{ml}$ saline formalin under a layer of white oil. The blood was allowed to "fix" for 10 minutes. The preserved blood was aspirated with a pasteur-type pipette and films of the blood were made on glass slides. The slides were stained with Wright's polychrome stain according to the method of Dacie. It has been established that treatment of the cells with saline formalin in no way alters the shape of the drepanocytes once formed, nor does it cause control red cells without sickle haemoglobin to become drepanocytes.

After dyeing, a cover slip was applied and the slides were examined with a light microscope. A total of 1,000 red cells were counted on each slide, 100 in each of 10 separate high power fields chosen at random and the percentage of sickle cells (drepanocytes) seen was recorded. At least some of these sickle cells could conceivably recover. Additional films were made from blood which was allowed to become fully oxygenated. Red cells not irretrievably damaged would recover their discoid shape, as describéd by Serjeant, Serjeant and Milner. ${ }^{19}$ Sickle cells remaining on these films would represent irreversibly sickled cells (ISC).

\section{Calculations}

Percentage of red cells containing haemoglobin $S$ In the patient bearing genes for both haemoglobin $S$ and haemoglobin $A$, each red cell has both haemoglobins; there is not a population of cells containing only haemoglobin $A$ and another containing haemologlobin $S$. Therefore, in the native state, all the red cells contain some haemoglobin $\mathrm{S}$; that is the percentage of red cells containing haemoglobin $S$ is 100 per cent.

After a transfusion or replacement of some of the patient's own blood with erythrocytes which contain exclusively haemoglobin $\mathrm{A}$ by an exchange transfusion, the percentage of cells containing haemoglobin $S$ declines proportionally to the haemoglobin A blood infused. In this patient. the haemoglobin $S$ was originally 36 per cent and all the red cells contained haemoglobin $S$. After exchange transfusion described below with blood containing exclusively haemoglobin $A$, the haemoglobin $S$ was 13.7 per cent. The percentage of red cells containing haemoglobin $S$ amidst the entire population of red cells now equalled:

$\frac{\text { New Hb S (in \%) }}{\text { Original Hb S (in \%) }}=\frac{13.7}{36} \times 100=38$ per cent.

Thus, after the exchange transfusion, the percentage of all the red cells now extant in the patient's circulation which contained haemoglobin $S$ was 38 per cent, instead of the original 100 per cent. Obviously, it is desirable to have the percentage of red cells which contain haemoglobin $S$ as low as is practicable, since only these cells can undergo sickling. 
Percentage of red cells containing haemoglobin $S$ uhich have sickled

The Sherman technique (q.v.) yields the per cent sickled red cells seen in the film. During a period of hypoxia or acidosis, an index of severity is the proportion of red cells liable to sickle; that is. those which contain any haemoglobin $S$ which have, in fact, undergone the sickle transformation. This proportion is given by the following formula:

Percent red cells Percent sickled red cells seen in film of the red which contain haemo- $=$ cells which contain globin $S$ and which haemoglobin $S$ amidst have sickled the entire percentage of the red cell population

The percentage of the red cells which contain haemoglobin $S$ amidst the entire population of red cells is 100 per cent in the native cells of the patient bearing the gene for sickle haemoglobin. After transfusion with blood which contains exclusively haemoglobin $A$, the sickle cell patient has two populations of red cells: one red cell which contains haemoglobin $S$ as well as haemoglobin $A$ and a second red cell which contains exclusively haemoglobin $A$. The proportion of red cells which contain any haemoglobin $S$ falls proportionate to the number of red cells containing exclusively haemoglobin $A$ which have been infused into the patient.

\section{Endocardial Viability Ratio (EVR)}

The term endocardial viability ratio was applied by Phillips $^{20}$ to a pressure time ratio formulated by Buckberg, et al., ${ }^{21.22}$ and is an extension of the coronary-ventricular pressure ratio established by Griggs and Nakamura. ${ }^{23}$ The ratio represents an attempt to relate the adequacy of coronary blood fow to the demand for blood by the myocardium. Briefly, the endocardial viability ratio is the ratio of the diastolic pressure time index to the systolic pressure time index. The diastolic pressure time index is the area under the diastolic pressure curve minus the left enddiastolic equivalent (or right atrial pressure whichever is the greater) in $\mathrm{mm} \mathrm{Hg} \cdot \mathrm{sec}^{-1}$. The systolic pressure time index, the tension time index of Samoff, et al. ${ }^{24}$ represents the area under the left ventricular pressure curve in $\mathbf{m m}$ $\mathrm{Hg} \cdot \mathrm{sec}^{-1}$, or. in clinical measurements, the area under the aortic systolic pressure curve. This ratio DPTI:SPTI is normally approximately one (0.8 to 1.2) and can be equated with equal total blood flow to the inner and outer layers of the heart per cardiac cycle. Used clinically this ratio is an index of global coronary flow to the endocardium; it cannot reflect exclusively regional perfusion. Its range of safety varies with oxygen carrying capacity of the blood, viscosity, temperature. coronary-vascular resistance or obstruction. For example, experimental studies in dogs with normal coronaries maintained at normothermia indicate that a value of less than $0.4-0.5$ (if the haemoglobin is $10.0 \mathrm{~g} / \mathrm{di}$ ) indicates subendocardial ischaemia while. in the presence of severe anaemia, the threshold for subendocardial ischaemia may be closer to $0.8 .^{25.26}$ We used a Datascope analogue computer which integrated mathematically the areas defined and provided an on-line display of the ratio DPTI:SPTI and heart rate. Pressure data were supplied to the computer directly by a cannula in the radial artery and by a Swan Ganz catheter in the pulmonary artery. At no time did the endocardial viability ratio approach potentially hazardous levels throughout this case.

\section{Ear Oximeter}

The Hewlett Packard (HP) 47201-A ear oximeter transmits light pulses through the pinna of the ear through a fiberoptic ear probe. The resulting light transmissions are measured by a photoelectric cell and the data are transformed according to an empirically determined formula. The oxygen saturation so derived is displayed in digital form. This instrument has been evaluated by Saunders and Rebuck ${ }^{27}$ and found to be accurate to within three per cent. This oximeter was attached to the patient throughout the operation and thereafter in the recovery room for continued monitoring of arterial oxygen saturation.

\section{Procedure}

In preparation for cardiopulmonary bypass circulation, the risks of the proposed operation as well as our plan for transfusion were carefully explained and informed consent was obtained. The patient underwent exchange transfusions with packed cells free of sickle cells. Six units of packed cells were exchanged. The final haemoglobin concentration was $12.7 \mathrm{~g} / \mathrm{dl}$. of which haemoglobin $S$ was 13.7 per cent. This proportion of haemoglobin $S$ containing blood is well within the range suggested by Lessin. Kurantsin-Mills. Klug and Weems and shown to have acceptable rheological characteristics. Blood reserved for 
TABLE I

Haematological Values

\begin{tabular}{|c|c|c|c|c|c|}
\hline & \multirow[b]{2}{*}{$\begin{array}{l}\text { Immedi- } \\
\text { ately after } \\
\text { anaesthesia } \\
\text { induction }\end{array}$} & \multicolumn{4}{|c|}{ Time with respect to cardiopulmonary bypas } \\
\hline & & $\begin{array}{l}18 \mathrm{~min} . \\
\text { after } \\
\text { starting }\end{array}$ & $\begin{array}{l}1 \text { hour } \\
\text { past }\end{array}$ & $\begin{array}{l}3 \text { hours } \\
\text { past }\end{array}$ & $\begin{array}{l}24 \text { hours } \\
\text { past }\end{array}$ \\
\hline Haemoglobin (g/100\%) & 12.7 & 6.9 & 83 & 12.1 & 12.7 \\
\hline Hb S electrophoresis (\% total Hb) & 13.7 & 13.6 & 13.7 & 8.1 & 5.2 \\
\hline $\begin{array}{l}\text { Sickling in mixed venous blood } \\
\text { ( } \% \text { of red blood cells) }\end{array}$ & 5 & 7 & 1 & 23 & 3 \\
\hline $\begin{array}{l}\text { Sickling in arterial blood } \\
\text { (\% of red blood cells) }\end{array}$ & 0 & 0 & 0 & 2 & 2 \\
\hline Red cells which contain $\mathrm{Hb} S$ & 37 & 37 & 37 & 22 & 14 \\
\hline Hb $S$ cells sickled $(\%)$ & 13 & 19 & 3 & 100 & 21 \\
\hline Hb S cells sickled irreversibly & nil & nil & nil & $\leq 40 \%$ & nil \\
\hline
\end{tabular}

the operation was screened by haemoglobin electrophoresis to ensure absence of haemoglobin $\mathrm{S}$.

In the operating room a cannula was inserted into the radial artery and a Swan Ganz catheter was inserted through the right basilic vein for monitoring of mixed venous oxygen saturation, cardiac output, and pulmonary wedge pressure. The oximeter (Hewlett Packard 47201-A) was attached to the left ear lobe.

Anaesthesia was induced with intravenous diazepam $0.3 \mathrm{mg} \cdot \mathrm{kg}^{-1}$ and fentanyl $0.5 \mathrm{mcg}$. $\mathrm{kg}^{-1}$. Tracheal intubation was performed after the administration of pancuronium bromide.

The extracorporeal pump was "primed" with $500 \mathrm{ml}$ of lactated Ringer's solution in 5 per cent dextrose, $500 \mathrm{ml}$ of thawed fresh frozen plasma, and $2.000 \mathrm{ml}$ of Ringer's solution. A "Travenol" membrane oxygenator in the circuit was used to sustain $\mathrm{Pa}_{\mathrm{O}_{2}}$ between 20.0 and $40.3 \mathrm{kPa}$ (15) to $303 \mathrm{~mm} \mathrm{Hg}$ ) and oxygen saturation at greater than 97 per cent.

Arterial blood hydrogen ion concentration was preserved between 39.81 and $29.51 \mathrm{nmol} / \mathrm{l}(\mathrm{pH}$ 7.40 to 7.53 ) with infusions of bicarbonate. The slightly alkalotic state was chosen as a prophylactic measure to obviate sickling of the red cells.

Triple aorto-coronary bypass with saphenous vein grafts was performed. Cardiopulmonary bypass with haemodilution, hypothermia and ischaemic cardioplegic arrest was employed. The patient's temperature was lowered to $27^{\circ} \mathrm{C}$ and his myocardial septal temperature fell to $18^{\circ} \mathrm{C}$ after arresting the heart with $600 \mathrm{ml}$ of cardioplegic solution consisting of lactated Riger's solution to which $\mathrm{KCl} 20 \mathrm{mmol} / 1, \mathrm{MgSO}_{4} 3 \mathrm{mmol} /$ and tromethamine (Tham) have been added to buffer the solution to $\mathrm{CH}^{+} 39.81 \mathrm{nmol} / /(\mathrm{pH} 7.4)$ at $20^{\circ} \mathrm{C}$. Another $200 \mathrm{ml}$ of cardioplegic solution was administered during the total ischaemic time of 47 minutes. Good flow was seen through all three grafts. No difficulty was encountered coming off bypass. The patient was taken to the recovery room with all vital signs intact.

At various intervals throughout and after the procedure, mixed venous and arterial blood samples were drawn simultaneously from the pulmonary artery catheter and the arterial cannula, re spectively. Sickling was then estimated by the Sherman technique, as described in Methods.

\section{Results}

The results are set down in Table J. At the completion of bypass venous sickling was less than observed before initiation of extracorporeal circulation.

In contrast to the operative and immediately postoperative periods, examination of venous blood three hours after operation revealed the greatest number of sickled red cells. Furthermore, at least half of these were irreversibly sickled cells.

At this time, haemoglobin $\mathbf{S}$ comprised but eight per cent of the total haemoglobin of 12.1 g/dl, reflecting blood loss during the operation and its replacement with blood which contained ondy haemoglobin A. This limited the proportion 
of the total population of red cells which could undergo sickling to 22 per cent; that is only 22 per cent of the patient's red cells contained haemoglobin $S$ at this time. However, since 22 per cent of all the red cells in the venous blood were actually seen to be sickled, all of the red cells which contained haemoglobin $\mathrm{S}$ underwent the sickling transformation.

Although, as stated earlier, the electrocardiogram showed no evidence of ischaemia or of electrical instability, and the oxygen content and saturation were maintained well within accepted limits, the patient began to shiver violently. The extremities appeared bluish with vasoconstriction and felt cool; the body core temperature had fallen to $35^{\circ} \mathrm{C}$. A warming blanket was applied immediately and the shivering was controlled with relaxant and sedation.

The trachea was extubated within 24 hours, and the patient was fully ambulatory four days after the operation. Two months after the operation he remains well and is free of anginal pain. His haemoglobin is $11.1 \mathrm{~g} / \mathrm{dl}$, of which haemoglobin $S$ is 32 per cent and the remainder haemoglobin $A$ with one per cent of haemoglobin $A_{2}$.

\section{Discussion}

The ability of red cells to traverse the microcirculation depends on their pliability. When the red cells are exposed to low oxygen tension, increased $\mathrm{cH}^{+}$(low $\mathrm{pH}$ ) or low temperature, haemoglobin $\mathbf{S}$ forms liquid crystals or tactoids within the red cell. The resultant crystallization causes deformation of the topology of the red cell. It assumes an irregular, sickle shape with consequent increased membrane rigidity and loss of the typical ability of red cells to undergo deformation and to recover their biconcave shape. The rigid sickled red cells cause increased blood viscosity leading to sludging, vascular occlusion with thrombi, further deoxygenation and more sickling.

The tendency for a red cell to undergo sickling is dependent upon the amount of haemoglobin $S$ in the cell. ${ }^{28.29}$ In patients with the sickle cell trait, the proportion of sickle haemoglobin with respect to haemoglobin A can vary from 25 to 45 per cent ${ }^{30}$ In vitro studies suggest that, in carriers who have a high concentration of haemoglobin $S$, the risk of sickling approaches that of patients with sickle cell disease. ${ }^{31}$ In our patient, those red cells which contained haemogiobin $S$ had an average of 38 per cent haemoglobin $S$. That the risk of sickling was present in our patient was shown by the results of the serial venous and arterial Sherman tests. These demonstrated that, while there was no evidence of sickling during and immediately after operation 22 per cent of the entire red cell population had undergone sickle transformation three hours after the surgery. Since only 22 per cent of the red cells could undergo sickling because only 22 per cent contained haemoglobin $\mathbf{S}$, this meant that, despite all reasonable precautions with respect to oxygenation, acid-base balance, osmolarity. haemodilution and cardioplegia and careful monitoring of all the relevant variables throughout the perioperative period, this patient managed to sickle all of his red cells containing haemoglobin $\mathrm{S}$. The probability is that this occurred because shivering and vasoconstriction from residual body temperature gradients induced hypoperfusion of tissues, which is well known to incite sickling. Had he not received exchange transfusions to replace nearly three quarters of the red celis containing haemoglobin $S$ with red cells containing exclusively haemoglobin $A$, many more of his cells might have sickled during this episode.

\section{Conclusion}

We regard the following prophylactic measures as contributing to the successful outcome in this patient.

1. Partial exchange transfusion with normal blood before operation to reduce the number of haemoglobin $S$ containing red cells to, at most, about one third of the entire red cell population. This means that even with severe anoxia, a maximum of one-third of the cells could sickle and possibly some of these could be restored with proper and rapid correction of hypoxia and acidosis. Furthermore, at this level, rheological abnormalities exerted by the sickle cells would be limited. Lessin and colleagues ${ }^{32}$ determined that as the proportion of sickle cells approached 40 per cent of the red cell population, the rheological properties of the blood were sufficiently altered that the resistance to flow rose sharply.

2. Maintenance of adequate $\mathrm{PO}_{2}$ of arterial blood and efficient and abundant tissue perfusion manifested by an adequate $\mathrm{PO}_{2}$ of venous blood during and after operation. In the presence of low cardiac output or, as in our patient, shivering. cold and stasis, oxygen extraction may become high, reducing the tissue and venous $\mathrm{PO}_{2}$ to levels of $2.66-3.99 \mathrm{kPa}(20-30 \mathrm{~mm} \mathrm{Hg})$ or lower, despite 
an adequate arterial $\mathrm{PO}_{2}$. In an environment that is this poor in oxygen sufficient deoxygenation of the haemoglobin can cause $\mathrm{Hb}$ AS red cells to undergo sickle transformation. ${ }^{32}$

3. Prevention, if possible, and immediate correction of any acidosis.

4. Abundant and repeated perfusion of the coronary circulation with an appropriate cardioplegic solution. This prevents stasis of blood in the myocardium. Oxygen tension can drop to a very low level when the aorta is occluded. This assumes special importance in these patients whose red cells contain haemoglobin $S$ and who are therefore susceptible to sickling associated with anoxia, with clogging of the myocardial circulation, stasis and tissue infarction as irrevocable complications.

Should any ischaemic complication or electrical instability occur independently, as they may in many patients, the effect could be amplified by vessels obstructed with sickle cells and the resulting local myocardial damage would be extended to poor global myocardial function and a relentless cycle of poor tissue function and myocardial failure, when even more electrical aberrations could become established.

All these measures clearly involved the anaesthetist. The first reflects close collaboration between the anaesthetist and the consulting haematologist. This collaboration extends throughout the preoperative, operative and postoperative periods, in particular with respect to preparation and blood replacement. The second and third measures are clearly the responsibility of the anaesthetist. Continuous monitoring and anticipation of hypoxia or acidosis is essential. Finally, the myocardial viability index, cardiac output. forward pressure measurements, as well as electrocardiographic analysis enable the anaesthetist to detect and to appraise any myocardial damage and, thus, the adequacy of myocardial perfusion in averting myocardialendocardial stasis and hypoxia.

The presence of sickle cell disease and sickle cell trait with the attending risk of sickling. thrombosis, infarction and haemolysis does not contraindicate anaesthesia and general surgery. where knowledge of this disease is coupled with proper care and judgement ${ }^{4.17 .32}$ The present case extends this premise to include patients with haemoglobin $S$ undergoing aorto-coronary by* pass surgery, providing extraordinary measures such as exchange transfusions are used. ${ }^{33,34}$ This assumes great importance, since $i t$ is expect- ed that, given the high incidence of coronary artery disease and the increasing availability of aorto-coronary bypass surgery, more patients with haemoglobin $S$ will be subjected to this operation.

\section{SUMMARY}

A triple aorto-coronary bypass was performed in a patient with sickle cell trait. Partial exchange transfusion with normal packed erythrocytes was used in preparation of the patient for extracorporeal circulation. hypothermia and cardioplegic arrest.

\section{RÉSUMÉ}

Les auteurs rapportent un cas de pontage aortocoronarian triple chez un patient atteint de drépanocytose latente. De tels patients porteurs du gène hétérozygote de l'anémie falciforme supportent en général bien l'anesthésie et la chirurgie si l'on évite les situations d'acidose, l'hypoxémie, la stase vasculaire et les épisodes hypotensifs. En préparation à la chirurgie, ils ont soumis leur malade à des transfusions d'échange (six culots) afin d'abaisser son taux d'hémoglobine $\mathbf{S}$. L'intervention s'est ensuite déroulée sans problème sous circulation extra-corporelle avec une hypothermie à $27^{\circ} \mathrm{C}$ et emploi de cardioplégie.

\section{REFERENCES}

I. Green, R.L.. Huntsman, R.G. \& Serueant, G.R. Sickle cell and altitude. Br. Med. J. i: 803 (1972).

2. JONES, S.R. Sudden death in sickle cell tmait. New Eng. 1. Med. 282: 323 (1970).

3. Ziperman, H.H. \& Graham, J.L. Abdominal crises associated with sicklemia and airplane flights. A report of two cases. A m. J. Surg. 103: 269 (1962).

4. Kotoney-Ahulu, F.I.D. Anaesthetic deaths and sickle cell irait. Lancet $i$ : 267 (1969).

5. GILBERTSON, A.A. Anaesthesia in West African patients with sickle-cell anaemia, haemoglobin SC disease, and sickle-cell trait. $\mathrm{Br}$. J. Anaesth. 37: $614(1965)$.

6. Gilbertson, A.A. The management of anaesthesia in sickle cell states. Proc. Roy. Soc. Med. $60: 631$ (1967).

7. SeARle. J.F. Anaesthesia in sickle cell traits: a review, Anaesthesia 28: 48 (1973).

8. Oduntan, S.A. \& IsaAC. W.A. Anaesthesia in patients with abnormal haemoglobin syndromes: a preliminary report. Br. J. Anaesth . 43: 1159(1971).

9. holtzmann, L., Finn. R.. Lichtman, H.C. \& HARMEL, M.H. Anaesthesia in patients with sickle 
cell disease. A review of 112 cases. Anesth. Analg. Curr, Res. 48: 566 (1963).

10. De Leval, M. Taswell, H. \& Bowie. E.J. Open-heart surgery in patients with inherited hemoglobinopathies, red cell dyscrasias and coagulopathies. Arch. Surg. 109:618 (1974).

11. DALAL. F.Y., SCHMidT, G.B.. BENNETT, E.J. \& RAmamurthy, S. Sickle cell trait. A report of a postoperative neurological complication. $\mathrm{Br}$ - $\mathrm{J}$. Anaesth. 46: 387 (1974).

12. SCHENK. E.A. Sickle cell trait and longitudinal sinue thrombosis. Ann. Int. Med. 60: 465 (1964).

13. Leachman, R.D. Miller. W. \& Atlas. 1. Sickle cell thrombi after open-heart surgery. Am. Heart J. $74: 267$ (1967).

14. Anderson. R., Cassek. M., Mullinox. G.L. \& ChapLin, H. Effects of normal cells on viscosity of sickle cell blood. Arch. Intern. Med. 11/: 286 (1963).

15. SZENTPETERY.S., RoberTSON, L. \& Lower, R.R. Complete repair of tetrology associated with sickle cell anemia and G-6-PD deficiency. J. Thorac. Cardiovasc. Surg. 72: 276 (1976).

16. Huisman. T.H.J. Normal and abnormal human haemoglobins. Adv. Clin. Chem. 6: 231 (1963).

17. Huisman. T.H.J. \& Jonxis. J.H.P. The Hemoglobin-techniques of identification. Marcel Bekker, Inc., New York and Basel. pp. 96-10l (1977).

18. Sherman, I.J. The sickling phenomenon, with special references to the differentiation of sickle cell anaemia from the sickle cell trait. Johns Hopkins Med. J. 67: 309 (1940).

19. Serueant, G.R.. Serneant. B.E. \& Milner. P.F. The irreversibly sickled cell: a determinant of haemolysis in sickle cell anaemia. Br. J. Haematol. 17:527 (1969).

20. Phillips. P.A., Marty. A. T. \& Miyamoto. A.M. A clinical method for detecting subendocardial ischaemia after cardio-pulmonary bypass. J. Thorac. Cardiovasc. Surg. 69: 30 (1975)

21. Buckererg. G.D.. Towers, B., Paglia, D.E. MULDER, D.G. \& MALONEY, J.V. Subendocardial ischemia after cardiopulmonary bypass. J. Thorac. Cardiovasc. Surg. 64:669 (1975).

22. Hoffman, J.E. \& BuckberG, G.D. The myocardial supply/demand ratio - a critical review. Am. J. Cardiol. 4l: 327 (1978).

23. Griggs, D.M. \& Nakamura, Y. Effects of coro- nary constriction on myocardial distribution of iodoantipyrene-1'31. Am. J. Physiol. 215: 1082 (1968).

24. Sarnoff. S.J., Braunwal. E, E., Welch. G.H.. Case, R.B., Stainsby, W.N. \& Macruz, R. Haemodynamic determinants of oxygen consump. tion of the heart with special reference to the tension time index. Am. J. Physiol. 192: 148 (1958).

25. Brazier, J. Cooper. N. \& Buckberg, G.D. The adequacy of subendocardial oxygen delivery: the interaction of determinants of fow arterial oxygen content and myocardial oxygen need. Circulation 49: 968 (1974).

26. Hoffman, I.E. Determinants and prediction of transmural myocardial perfusion. Circulation 58 : 381 (1978).

27. Saunders. N.A. Powles, A.C.P. \& Remuck, A.S. Ear oximetry: accuracy and practicality in the assessment of arterial oxygenation. Amer. Rev. Resp. Dis. 113: 745 (1976)

28. Kotoney-Ahulu, F.I.D. Patterns of clinical haemoglobinopathy, East Afr. Med. J. 46: 149 (1969).

29. Dalal. F.Y., Schmidt, G.B., Bennett, E.J. \& Ramamurthy, S. Sickle cell trait. Br. J. Anaesth. 46: 387 (1974).

30. NeIL. J.V., Wells, I.C. \& Itano, H.A. Familial differences in the proportion of abnormal hemoglobin present in the sickle-cell trait. J. Clin. Invest. 30: $1120(1951)$.

31. Howell.s. T.H., Huntsman, R.G., Bors, J.E. \& Maнmood, A. Anaesthesia and sickle cell haemoglobin. Br. J. Anaesth. 44: 975, 1972.

32. Lessin, L.S... Kurantsin-Mills. J., Klug, P.P. \& WEEMS, M.B. Determination of optimal mixtures of AA and SS erythrocytes for transfusion. In, Erythrocyte Membranes: Recent Clinical and Experimental Advances. (Ed.) Kruckeberg, W.C., Eaton, J. and Brewer, G. Alan R. Liss, New York, pp. 123-134 (1970).

33. Howells, T.H. \& Huntsman, R.G. Anaesthesia in sickle cell states. Anaesthesia 28: 339 (1973).

34. HUEHNS. E.R. Disease of haemoglobin synthesis. In, Recent Advances in Medicine, 16th edition. (Ed.) Baron, D.N., Compston, N. and Dawson, A.M. Churchill Livingsione, Edinburgh, p. 373 (1973). 